\title{
Foreign Gene Expression in the Mouse Cauda Epididymis is Regulated by Androgens
}

\author{
La Expresión de Genes Extraños en la Cauda del \\ Epidídimo del Ratón Está Regulada por Andrógenos
}

Pedro Esponda*

ESPONDA, P. Foreign gene expression in the mouse cauda epididymis is regulated by androgens. Int. J. Med. Surg. Sci, 2(4):671-678, 2015.

SUMMARY: This paper deals with the efficiency of in vivo gene transfer to the mouse cauda epididymis and its relation to androgens. Previous experiments in the female reproductive tract have indicated that the efficiency of transfection is related to the hormonal stage of the animal, nevertheless no analysis have been done in the male tract. We used in vivo gene transfer to the mouse cauda epididymis employing a gene construction that expresses the Green Fluorescent Protein (GFP). Untreated and Testosterone treated males were employed. Testosterone injections ( $5 \mu \mathrm{g} / \mathrm{g}$ weight) were done from 2 days before the gene transfer, and treatment continued each day during a total period of 15 days. Fluorescence microscopy observations showed the expression of GFP in the cytoplasm of the principal cells in the epididymal tubules. The application of the QWin Program that measures the percentage of fluorescent areas showed that they are increased in the epididymis of treated males. This increase was particularly observed two days after gene injections (from $32.24 \%$ in untreated animals to $47.62 \%$ in testosterone treated males) and after seven days (from 29.98 $\%$ to $43.05 \%$ ). The possibility to improve transfection efficiency would increase the knowledge on epididymal physiology and would permit to modify the fertilizing capacity in mammals.

KEY WORDS: Androgens; Epididymis; Gene transfer; Transfection; Testosterone.

\section{INTRODUCTION}

The epididymis has an important function on the sperm maturation phenomena and on the acquisition of the sperm fertilizing ability (Bedford, 1979; Cooper, 1986; Kirchhoff et al., 1997). Several proteins secreted by the epithelium of the epididymis become associated to the spermatozoon membrane and have some functions during sperm capacitation, acrosome reaction and sperm/egg interaction (Jones, 1998; Lye \& Hinton, 2004). From this point of view, the possibility to modify the characteristics and functions of the epithelial cells of the epididymis is an important goal focussed to the knowledge and control of reproduction.
Gene transfer (or transfection) consists in the introduction of foreign genes into cells, tissues or complete animals (Ledley, 1995; Mulligan, 1993). The number of cells that expresses the foreign gene/s and the time of expression are related to the efficiency of transfection (Anderson, 1998; Mulligan, 1993). There is low transfection efficiency when the foreign gene is expressed in a few cells or during very short time periods. In other cases, the efficiency is higher because the foreign gene is expressed in a large number of cells and/or occurs during long time periods (Danko et al., 1997).

*Centro de Investigaciones Biológicas, CSIC, Madrid, Spain.

This paper was partially supported by Grant BFU2008-2947-C02-02 from DGICYT (Spain).

$\left(^{*}\right)$ This paper is dedicated to the memory of Prof. Dr. E. Bustos- Obregón by his enormous contribution to the progress of Biology of Reproduction in Chile. 
ESPONDA, P. Foreign gene expression in the mouse cauda epididymis is regulated by androgens. Int. J. Med. Surg. Sci., 2(4):671-678, 2015.

Gene transfer procedures have been widely applied in order to know the function of different genes and/or proteins (Ledley; Mulligan). In vitro and in vivo methods have been used and the in vivo procedures have been the basis when gene therapy was applied (Verma \& Weitzman, 2005; Ledley et al., 2014). Gene constructions used for transfections sometimes consist in naked DNA (Wolff \& Budker, 2005). Nevertheless, gene vectors are usually employed and the most frequently used have been some adenovirus or retrovirus (Daftary \& Taylor, 2003). Non-viral methods include the use of different molecules or structures such as liposomes, neutral lipids, polymeric matrixes, nanoparticles and others (Mulligan; Hart, 2005; Vasir \& Labhasetwar, 2006). Lipids and Liposomes can be easily associated to nucleic acid molecules and do not show a deleterious effect on cells, but their transfection efficiency is sometimes low (Ledley). Other procedures as in vivo electroporation (Trezise et al., 2003) or the bombardment with high velocity microprojectiles (Zelenin et al., 1993) have been also successfully employed. All these methods are closely related to gene therapy techniques which are beginning to be applied in medicine (Ledley et al.).

The Green Fluorescent Protein (GFP) is a reporter gene widely used in last years. GFP is a fluorescent protein naturally present in a jellyfish and has been used because its expression can be easily observed in fixed or living cells (Kendall \& Badminton, 1998).

In the male genital tract in vitro transfections have been developed using epididymal cell lines (Kirchoff et al., 2004; Dufresne et al., 2005; Yu et al., 2006). In the mouse, the vas deferens was in vivo transfected using the GFP gene construction (Valenzuela et al., 2002). In the human an in vitro transfection of the vas was also undertaken (Esponda et al., 2004). The epididymis of the rat was transfected in vivo using an electroporation procedure (Kirby et al., 2004), and in the mouse DNA-Lipids complexes have been used for transfection of the cauda epididymis and transgene expression was observed in the epithelial cells and its secretions (Esponda \& Carballada, 2009).

In the female tract, transfections developed in the uterus and oviduct demonstrates that the efficiency of transfection was in relation to the cycle of the uterine epithelium, which is directly associated to the hormonal stage (Relloso \& Esponda, 2000). Results showed that best efficiency was observed during the meta-oestrus and pseudo pregnancy stages. During these stages the epithelial conditions are very similar, and there are high concentrations of progesterone and lower of oestradiol (Relloso \& Esponda). Nevertheless, no studies have shown the influence of androgens on the transfection efficiency of the male genital tract. For this reason we analyze the role of testosterone administration on the efficiency of transfection in the mouse epididymis.

\section{MATERIAL AND METHOD}

Adult male mice (CD1 strain) bred in our colony were used. They were sexually mature and maintained in a cycle of $12 \mathrm{~h}$ light : $12 \mathrm{~h}$ dark, at constant temperature and with food and water ad libitum. Animals were killed by ether anaesthesia and in all cases the epididymis was removed in PBS buffer. The animal protocol used was in accordance with the law 1201/2005 on Animal Protection of Spain, the European Union Agreement about Vertebrate Animal Protection (3/18/1986) and in accordance with the NIH Guide and the CSIC (Spain) ethical Committee for the care and use of laboratory animals.

The commercial plasmid pGeneGrip (GTS. CA. USA) that encodes the green fluorescent protein (GFP) under the control of hCMV IE promoter/enhancer was employed. This plasmid is rhodamine labelled then it can be located inside cells and tissues after transfection. The lipid FuGENE 6 (Roche. Mannheim. Germany) was employed as gene vector (Arnold et al., 2006; Selinger et al., 2005). DNA and FuGENE were mixed in Dulbecco's Medium such that 125$200 \mathrm{ng}$ DNA was mixed with $1 \mathrm{ml}$ of the commercial lipid. This mixture was re-suspended in $50 \mathrm{ml}$ of medium. Animals were anaesthetized using an intraperitoneal injection of Rompun and Ketolar (Parke-Davis, Madrid, Spain): $4 \mathrm{mg}$ of Ketolar and $0.35 \mathrm{mg}$ of Rompun in $1 \mathrm{~mL}$ of PBS were employed, and $21 \mathrm{ml} / \mathrm{g}$ of weight were injected. After a simple surgical incision the left epididymis was exposed and, using a glass microcapillary needle (Huguet \& 
Esponda 1998) filled with the DNA/Liposome mixture, 1-2 $\mathrm{ml}$ of this solution was gently injected into the lumen of the distal region of the cauda epididymis.

The number of males injected with pGeneGrip was 41 (Table I). Some of these males (14) received a subcutaneous injection of testosterone (Sigma Chem Co., St. Louis, MO) using as vehicle corn oil. The first injection was done two days before gene injection. A dose of $5 \mu \mathrm{g} / \mathrm{g}$ weight was injected daily during 17 days. Injected animals were killed on days $2,7,15$ after gene injections. Control animals were 6 mice that were injected with an equal amount of the vehicle only.

Treated and control cauda epididymis were dissected under a microscope, divided in small pieces and treated as follows: fixed in $1 \%$ paraformaldehyde in PBS during one hour. After exhaustive washings they were sectioned using a Fricocut E Cryostat (Reichert-Jung, Wien, Austria). Sections of about $10-20 \mathrm{~mm}$ were mounted on poly-L-lisine treated slides. For observations, samples were mounted using a PBS solution containing Glicerol $10 \%$, Vectashield $1 \%$ and 10 mM Hoechst 33342 (Sigma. St.Louis, MO USA). Vectashield (Vector Labs. Burlingame, CA USA) was employed to avoid quenching of the fluorescence and Hoechst 33342 for DNA stain. Slides were observed and photographed in a Nikon fluorescence microscope or captured using a microscope equipped with a CCD system (200A Polytronics, Emsworth, UK).

To check the efficiency of gene transfection we applied the QWin program from Leica Microsystems (Wetzlar, Germany). We employed 15 sections from each time period. The program measures both the total epithelial area and the fluorescent regions in each section, and calculates the percentage of these last areas.

Table I. Percentages of GFP fluorescent areas in the mouse cauda epididymis calculated by the QWin Program.

\begin{tabular}{lccc}
\hline & \multicolumn{3}{c}{ Time after Gene Injection (Days) } \\
& $\mathbf{2}$ & $\mathbf{7}$ & $\mathbf{1 5}$ \\
\hline - Testosterone & $32.24(9)$ & $29.98(10)$ & $22.37(8)$ \\
+ Testosterone & $47.62(5)$ & $43.05(5)$ & $30.08(4)$ \\
Controls & $1.60(2)$ & $2.01(2)$ & $1.80(2)$ \\
\hline
\end{tabular}

Numbers in parenthesis indicated the number of animals used.

\section{RESULTS}

The presence of the gene construction was recognized by the presence of the red fluorescence of the Rhodamine molecule associated to the $\mathrm{p}$-GeneGrip. Treated cauda epididymides showed numerous red fluorescence spots, indicating the presence of the gene construction inside the epithelium. Red fluorescent points appeared located into the epithelial cells in both the cytoplasm and the nucleus (Fig. 1). Some areas of the cauda epididymis appeared transfected and sometimes in a single section several regions showed fluorescence (Fig. 1). Control preparations did not show this red fluorescence.

The green fluorescence of the GFP gene construction was clearly observed at all time periods analyzed. The most intense fluorescence was observed 2 days after testosterone treatment, and in some cases all the diameter of a tubule in a section appeared fluorescent. Fluorescence areas appeared as patches of different extensions along the epididymal tubules (Fig. 3). A decreasing green fluorescence was seen 7 and 15 days after injection. The fluorescence was clearly located in the cytoplasm of epithelial principal cells and the nuclei appeared free of fluorescence (Fig. 2).

The QWin Program used to measure the percentage of green fluorescent areas showed variations in dependence of the time periods after gene injection. Epididymides collected 2 days after the gene injection showed fluorescence in the $32.24 \%$ of the epithelium; in the $29.98 \%$ after 7 days and in the $22.37 \%$ after 15 days (Table I). In the testosterone treated animals the QWin Program analysis showed a notable increase in the percentage of fluorescent areas during all time periods analyzed, particularly after 2 days in which the $47.62 \%$ appeared fluorescent and after 7 days with a $43.05 \%$ of fluorescence (see Table I). In all cases controls preparations did not showed a notorious green fluorescence. 


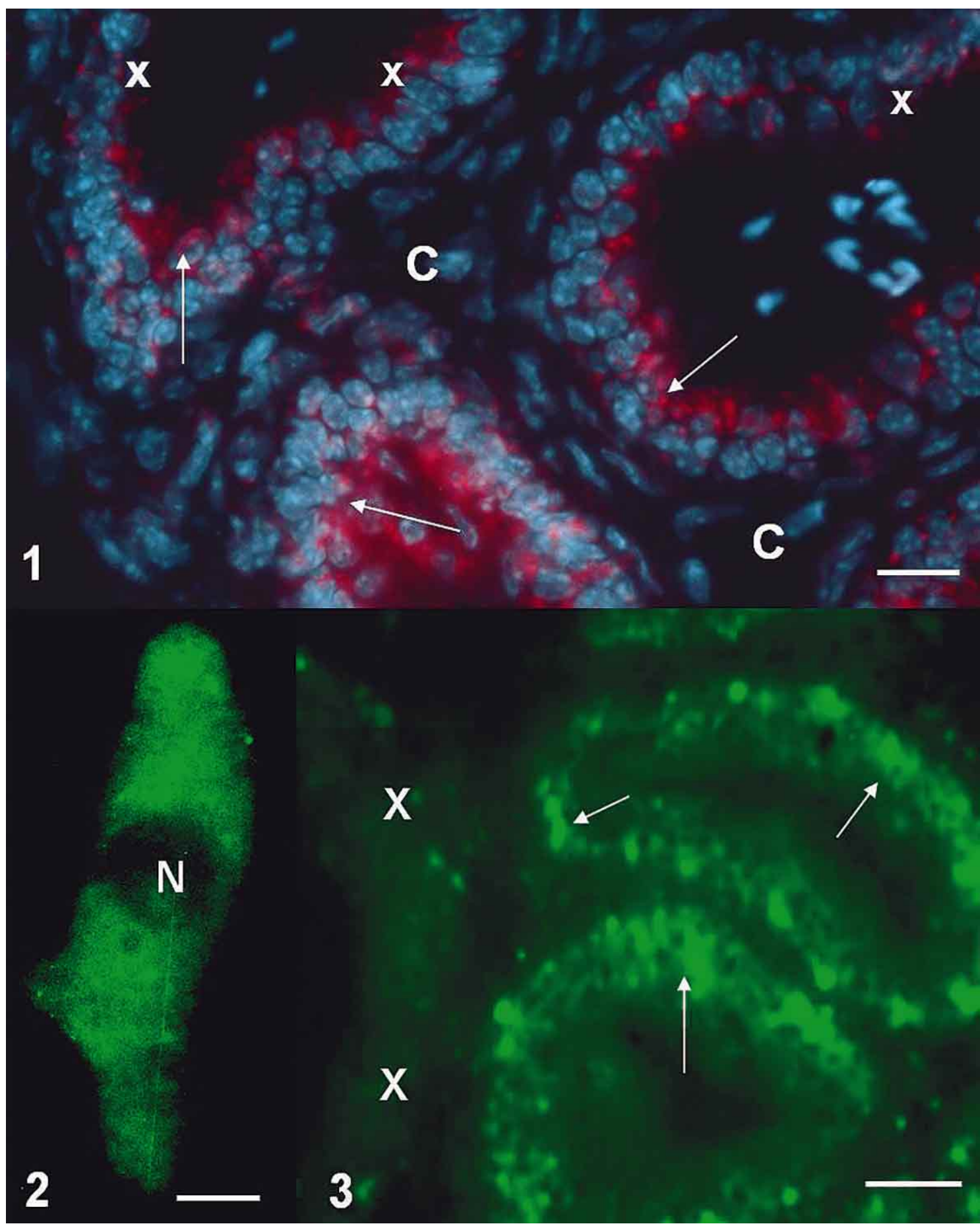

Fig. 1. In 1, the red fluorescence of the Rhodamine present in the pGeneGrip construction is observed in cryostat sections of the cauda epididymis two days after gene injection and androgen supplementation. Groups of fluorescent dots appeared as patches in some tubules (arrows) but other tubule regions are devoid of fluorescence (indicated by $\mathrm{x}$ ). C: show connective tissue regions. 2. GFP gene expression two days after gene injection and with androgen supplementation. Green fluorescence appears as patches in two tubules (arrows) but not in other (x). 3. GFP gene expression in an epithelial cell two days after gene injection and androgen supplementation. The green fluorescence is observed only in the cytoplasm but the nucleus is devoid of fluorescence $(\mathrm{N})$. The bars. In 1 and 2: $20 \mathrm{m \mu}$, in 3: $5 \mathrm{m \mu}$. 
ESPONDA, P. Foreign gene expression in the mouse cauda epididymis is regulated by androgens. Int. J. Med. Surg. Sci., 2(4):671-678, 2015.

\section{DISCUSSION}

Gene transfer to the male reproductive tract has been developed in recent years. Some authors have used in vitro procedures to transfect epididymal cell lines in order to analyze the expression of different genes and/or the role of some proteins (Kirchoff et al., 2004; Dufresne et al.; Yu et al.). Methods for in vivo gene transfer was applied to the mouse vas deferens using as gene constructions the GFP and a Bgalactosidase of nuclear expression (Valenzuela et $a /$.$) . In this case a foreign gene expression$ occurred in the $13.3 \%$ of cells after employing the GFP gene construction and expression was observed during three months in some areas of the vas. Furthermore, two gene constructions that express secretory proteins have been also used to transfect the vas. These constructions were the pSEAP-control that expresses a secretory form of Alkaline Phosphatase, and the pGFP-Ctk-37 that expresses a secretory form of GFP. In both cases the vas fluids from the treated animals showed a notorious increase of both secreted proteins (Valenzuela et al.). In the human, pieces of vas deferens collected from vasectomies were in vitro transfected using the GFP as a reporter gene and liposomes or neutral lipids as gene vectors (Esponda et al.). In this case GFP gene expression appeared exclusively in the vas epithelium and occupied a $9-10 \%$ of the epithelial area. The rat epididymis was recently transfected in vivo using an electroporation procedure to analyze the expression and function of some genes in the initial segment of the epididymis (Kirby et al.). In the mouse, DNA-Lipid complexes have been also used for transfection of the cauda epididymis (Esponda \& Carballada). After a microinjection of the cauda tubules with the GFP gene construction, foreign gene expression was observed during a maximum of $15 \mathrm{~d}$ and a third of the epithelial cells of the cauda express the foreign gene. The pSEAP-control gene construction that expresses a secretory form of Alkaline Phosphatase was also employed to transfect the mouse cauda epididymis. Results showed that a significant increase of the enzyme appeared in the fluid secreted by the cauda and in the cytosol of epithelial cells $7 \mathrm{~d}$ after gene injection (Esponda \& Carballada). All these results suggest that using a simple in vivo transfection procedure the cells and secretions of the male reproductive tract can be modified.

The image of the GFP transfected epididymis showing a diffuse and intense fluorescence in the cytoplasm of epithelial cells is similar to that described for other GFP transfected cells (Olson et al., 1995; Kendall \& Badminton, 1998). The fluorescent cells observed in the epididymal epithelium are undoubtedly the principal cells which are the most numerous in the epididymal epithelium. The image of the transfected epididymis in which the epithelium appear as the only positive region has been shown before in the rat (Kirby et al., 2004) and in the mouse (Esponda \& Carballada). When in vivo transfections were used and gene constructions were instilled inside tubular organs, the unique transfected region is the epithelium. This result has been observed in different tissues as trachea (Fortunati et al., 1996), alveolar epithelium (Katkin et al., 1995), vas deferens (Valenzuela et al.; Esponda et al.) and in the uterus and oviduct (Charnock-Jones et al., 1997; Relloso \& Esponda).

Female tract experiments showed that the efficiency of transfection was related to the cycle of the uterine epithelium, which is directly associated to the hormonal stage of the animal (Relloso \& Esponda). Results showed that a low number of positive animals occurred in immature, di-oestrus, pro-oestrous and oestrous groups, and that the highest numbers were observed during the meta-oestrus and pseudo pregnancy stages. During these stages the epithelial conditions are very similar, and there are high concentrations of progesterone and lower concentrations of oestradiol (Relloso \& Esponda). During meta-oestrous and pseudopregnancy the uterine epithelium is well developed and the diameter of glands is the greatest (Brenner \& Maslar, 1988). On the contrary, in young animals or during di-oestrous the epithelium is inactive, and during prooestrous or oestrous the epithelium is in a growing process. Studies of transfection in the rabbit uterus have shown that the transduction pattern of uterine tissues varies significantly with the reproductive cycle (Laurema et al., 2007). 
ESPONDA, P. Foreign gene expression in the mouse cauda epididymis is regulated by androgens. Int. J. Med. Surg. Sci., 2(4):671-678, 2015.

In the male the effects of hormones on transfection efficiency has not been analyzed. Our results clearly show that in the mouse cauda epididymis the percentage of transfected areas are increased after testosterone administration. The effects of androgens on the male tract and accessory glands are well known (Mann \& Lutwack-Mann, 1981). Androgen withdrawal reduces the volume of the epididymis and the epithelium becomes reduced in height. Androgens regulate specific gene expression in the epididymal epithelium (Jones et al., 1980; Brooks, 1987) and androgen withdrawal produces dramatic changes in the pattern of epididymal secreted proteins (Moore, 1981; Esponda \& Bedford, 1986). The role of androgens is not restricted to regulating gene expression, but it also ensures cell survival, and castration induces a wave of apoptosis in the epithelium (Fan \& Robaire, 1998). In several cases it can be observed that androgen supplementation reverses some of these changes and that is capable to restoring several characteristics of some reproductive organs (Gooren, 2003; Jara et al., 2004). Then it seems logical that androgen supplementation increases the transfection efficiency. The efficiency of transfection is also related to several factors as the distribution and extracellular half-life of DNA, the efficiency of DNA uptake into the cells, the grade of degradation of DNA within the cell, the rate of transcription, the stability of m-RNA and the rate of translation (Ledley \& Ledley, 1994) Also cell death affect the efficiency because the reporter protein could be toxic or because the immune system recognizes and eliminates the foreign gene products together with the cells expressing them (Anderson, 1998). It seems very probable that androgens stimulate some of these factors and then the efficiency of transfection. Recently, authors show that some molecules like trehalose is an important factor to mediate and enhance gene transfer in mouse epididymal epithelial cells (Qu et al., 2014).

The increase of transfection efficiency in the mammalian epididymis could be of interest for future applications. The possibility to use some special or antisense genes would provide the opportunity to know new insights on the epididymal function and also to manipulate the fertilizing capacity of spermatozoa.

ESPONDA, P. La expresión de genes extraños en la cauda del epidídimo del ratón está regulada por andrógenos. Int. J. Med. Surg. Sci., 2(4):671-678, 2015.

RESUMEN: Este artículo trata sobre la eficiencia de transferencia génica in vivo a la cauda del epidídimo del ratón y su relación con los andrógenos. Experimentos previos en el tracto reproductivo femenino han indicado que la eficacia de la transfección se relaciona con la etapa hormonal del animal, sin embargo, ningún análisis se ha realizado en el tracto masculino. Se realizó la transferencia de genes in vivo a la cauda del epidídimo del ratón empleando una construcción de genes que expresan la proteína verde fluorescente (GFP). Se utilizaron ratones macho con y sin tratamiento de testosterona. Las inyecciones de testosterona ( 5 $\mathrm{mg} / \mathrm{g}$ de peso) se realizaron a partir de 2 días antes de la transferencia de genes, y el tratamiento se continuó diariamente, durante un periodo total de 15 días. Las observaciones de microscopía de fluorescencia demostraron la expresión de GFP en el citoplasma de las células principales en los túbulos del epidídimo. La aplicación del Programa QWin que mide el porcentaje de áreas fluorescentes, mostró un incremento en el epidídimo de los machos tratados. Este incremento se observó en particular dos días después de las inyecciones de genes (desde 32,24 \% en los animales no tratados a 47,62 \% en machos tratados con testosterona) y después de siete días (desde $29,98 \%$ a 43,05 \%). La posibilidad de mejorar la eficiencia de la transfección podría aumentar el conocimiento sobre la fisiología del epidídimo y permitiría modificar la capacidad de fertilización en los mamíferos.

PALABRAS CLAVE: Andrógenos; Epidídimo; Transferencia de genes; Transfección; Testosterona.

\section{REFERENCES}

Anderson, W. F. Human gene therapy. Nature, 392(6679 Suppl.):25-30, 1998.
Arnold, A. S.; Laporte, V.; Dumont, S.; Alpert-Collin, A.; Erbacher, P.; Coupin, G. ; Levy, R. ; Poindron, 
P. \& Gies, J. P. Comparing reagents for efficient transfection of human primary myoblasts: FuGENE 6, Effectene and ExGen 500. Fundam. Clin. Pharmacol., 20(1):81-9, 2006.

Bedford, J. M. Evolution of the sperm maturation and sperm storage functions of the epididymis. In: Fawcett, D. W. \& Bedford, J. M. (Eds.). The Spermatozoon - Maturation, Motility, Surface Properties and Comparative Aspects. Baltimore, Urban and Schwarzenberg, 1979. pp.7-22.

Brenner, R. M. \& Maslar, I. A. The primate oviduct and endometrium. In: Knobil, E. \& Neil, J. D. (Eds.). The Physiology of Reproduction. Vol I. 2nd ed. New York, Raven Press, 1988. pp.30329.

Brooks. D. E. Androgen-regulated epididymal secretory proteins associated with post-testicular sperm development. Ann. N. Y. Acad. Sci., 513:179-94, 1987.

Charnock-Jones, D. S.; Sharkey, A. M.; Jaggers, D. C.; Yoo, H. J.; Heap, R. B. \& Smith, S. K. In-vivo gene transfer to the uterine endometrium. Human Reprod., 12(1):17-20, 1997.

Cooper, T. G. The Epididymis, Sperm Maturation and Fertilisation. Heidelberg, Springer Verlag, 1986.

Daftary, G. S. \& Taylor, H. S. Reproductive tract gene transfer. Fertil. Steril., 80(3):475-84, 2003.

Danko, I.; Williams, P.; Herweijer, H.; Zang, G.; Latendresse, J. S.; Bock, I. \& Wolff, J. A. High expression of naked plasmid DNA in muscles of young rodents. Hum. Mol. Genet., 6(9):143543, 1997.

Dufresne, J.; St-Pierre, N.; Viger, R. S.; Hermo, L. \& Cyr, D. G. Characterization of a novel epididymal cell line to study epididymal function. Endocrinology, 146(11):4710-20, 2005.

Esponda, P. \& Bedford, J. M. The influence of body temperature and castration on the protein composition of fluid in the rat cauda epididymidis. J. Reprod. Fertil., 78(2):505-14, 1986.

Esponda, P. \& Carballada, R. In-vivo gene transfer induces transgene expression in cells and secretions of the mouse cauda epididymis. Mol. Hum. Reprod., 15(6):355-61, 2009.

Esponda, P.; Goldstein, M. \& Witkin, S. S. In vitro transfection of the human vas deferens using DNA-liposome and DNA-neutral lipid complexes. Fertil. Steril., 81(1):171-5, 2004.
Fan, X. \& Robaire, B. Orchidectomy induces a wave of apoptotic cell death in the epididymis. Endocrinology, 139(4):2128-36, 1989.

Fortunati, E.; Bout, A.; Zanta, M. A.; Valerio, D. \& Scarpa, M. In vitro and in vivo gene transfer to pulmonary cells mediated by cationic liposomes. Biochem. Biophys. Act., 1306(1):55-62, 1996.

Gooren, L. Androgen deficiency in the aging male: benefits and risks of androgen supplementation. J. Steroid Biochem. Molec. Biol., 85(2-5):349$55,2003$.

Hart, S. L. Lipid carriers for gene therapy. Curr. Drug Deliv., 2(4):423-8, 2005.

Huguet, E. \& Esponda, P. Foreign DNA introduced into the vas deferens is gained by mammalian spermatozoa. Mol. Reprod. Dev., 51(1):42-52, 1998.

Jara, M.; Carballada, R. \& Esponda, P. Age-induced apoptosis in the male genital tract of the mouse. Reproduction, 127(3):359-66, 2004.

Jones, R. Plasma membrane structure and remodelling during sperm maturation in the epididymis. J. Reprod. Fertil. Suppl., 53:73-84, 1998.

Jones, R.; Brown, C. R.; Von Glós, K. I. \& Parker, M. G. Hormonal regulation of protein synthesis in the rat epididymis. Characterization of androgen-dependent and testicular fluiddependent proteins. Biochem. J., 188(3):66776, 1980.

Katkin, J. P.; Gilbert, B. E. ; Langston, C. ; French, K. \& Beaudet, A. L. Aerosol delivery of a betagalactosidase adenoviral vector to the lungs of rodents. Hum. Gene Ther., 6(8):985-95, 1995.

Kendall, J. M. \& Badminton, M. N. Aequorea victoria bioluminescence moves into an exciting new era. Trends. Biotechnol., 16(5):216-24, 1998.

Kirby, J. L.; Yang, L.; Labus, J. C.; Lye, R. J.; Hsia, N.; Day, R.; Cornwall, G. A. \& Hinton, B. T. Characterization of epididymal epithelial cellspecific gene promoters by in vivo electroporation. Biol. Reprod., 71(2):613-9, 2004.

Kirchhoff, C.; Pera, I.; Derr, P.; Yeung, C. H. \& Cooper, T. The molecular biology of the sperm surface. Post-testicular membrane remodelling. Adv. Exp. Med. Biol., 424:221-32, 1997. 
ESPONDA, P. Foreign gene expression in the mouse cauda epididymis is regulated by androgens. Int. J. Med. Surg. Sci, 2(4):671-678, 2015.

Kirchhoff, C.; Araki, Y.; Huhtaniemi, I.; Matusik, R. J.; Osterhoff, C.; Poutanen, M.; Samalecos, A.; Sipilä, P.; Suzuki, K. \& Orgebin-Crist, M. C. Immortalization by large T-antigen of the adult epididymal duct epithelium. Mol. Cell. Endocrinol., 216(1-2):83-94, 2004.

Laurema, A. ; Lumme, S.; Heinonen, S. E. ; Heinonen, S. \& Ylä-Herttuala, S. Transduction patterns and efficiencies in rabbit uterine tissues after intraluminal uterine adenovirus administration vary with the reproductive cycle. Acta Obstet. Gynecol. Scand., 86(9):1035-40, 2007.

Ledley, F. D. Nonviral gene therapy: the promise of genes as pharmaceutical products. Hum. Gene Ther., 6(9): 1129-44, 1995.

Ledley, T. S. \& Ledley, F. D. Multicompartment, numerical model of cellular events in the pharmacokinetics of gene therapies. Hum. Gene Ther., 5(6):679-91, 1994.

Ledley, F. D. ; McNamee, L. M. ; Uzdil, V. \& Morgan, I. W. Why commercialization of gene therapy stalled; examining the life cycles of gene therapy technologies. Gene Ther., 21(2):188-94, 2014.

Lye, R. J. \& Hinton, B. T. Technologies for the study of epididymal-specific genes. Mol. Cell Endocrinol., 216(1-2):23-30, 2004.

Mann, T. \& Lutwak-Mann, C. Male Reproductive Function and Semen. Berlin, Springer Verlag, 1981.

Moore, H. D. Effects of castration on specific glycoprotein secretions of the epididymis in the rabbit and hamster. J. Reprod. Fertil., 61(2):34754, 1981.

Mulligan, R. C. The basic science of gene therapy. Science, 260(5110):926-32, 1993.

Olson, K. R. ; McIntosh, J. R. \& Olmsted, J. B. Analysis of MAP 4 function in living cells using green fluorescent protein (GFP) chimeras. J. Cell Biol., 130(3):639-50, 1995.

Qu, B.; Gu, J.; Shen, J.; Qin, J.; Bao, J.; Hu, Y.; Zeng, W. \& Dong, W. Trehalose maintains vitality of mouse epididymal epithelial cells and mediates gene transfer. PLoS One, 9(3):e92483, 2014.

Relloso, M. \& Esponda, P. In-vivo transfection of the female reproductive tract epithelium. Mol. Hum. Reprod., 6(12): 1099-105, 2000.
Selinger, C. I. ; Day, C. J. \& Morrison, N. A. Optimized transfection of diced siRNA into mature primary human osteoclasts: inhibition of cathepsin $\mathrm{K}$ mediated bone resorption by siRNA. J. Cell. Biochem., 96(5):996-1002, 2005.

Trezise, A. E. ; Palazon, L. ; Davies, W. L. \& Colledge, W. H. In vivo gene expression: DNA electrotransfer. Curr. Opin. Mol. Ther., 5(4):397404, 2003.

Valenzuela, M.; Relloso, M. \& Esponda, P. In vivo transfection of the mouse vas deferens. J. Exp. Zool., 293(5):532-40, 2002.

Vasir, J. K. \& Labhasetwar, V. Polymeric nanoparticles for gene delivery. Expert Opin. Drug. Deliv., 3(3):325-44, 2006.

Verma, I. M. \& Weitzman, M. D. Gene therapy: twenty-first century medicine. Annu. Rev. Biochem., 74:711-38, 2005.

Wolff, J. A. \& Budker, V. The mechanism of naked DNA uptake and expression. Adv. Genet., 54:320, 2005.

Yu, X.; Suziki, K.; Wang, Y.; Gupta, A.; Jin, R.; Orbegin-Crist, M. C. \& Matusik, R. The role of forkhead box A2 to restrict androgen-regulated gene expression of lipocalin 5 in the mouse epididymis. Mol. Endocrinol., 20(10):2418-31, 2006.

Zelenin, A. V.; Alimov, A. A.; Zelenina, I. A.; Semenova, M. L.; Rodova, M. A. ; Chernov, B. K. \& Kolesnikov, V. A. Transfer of foreign DNA into the cells of developing mouse embryos by microprojectile bombardment. F. E. B. S. Lett., 315(1):29-32, 1993.

Correspondence to:

Dr. Pedro Esponda

Centro de Investigaciones Biológicas, CSIC

Ramiro de Maeztu 9

28040, Madrid

SPAIN

Telephone: 34606740254

Email: pesfer@yahoo.com

Received: $14-10-2015$

Accepted: 28-11-2015 